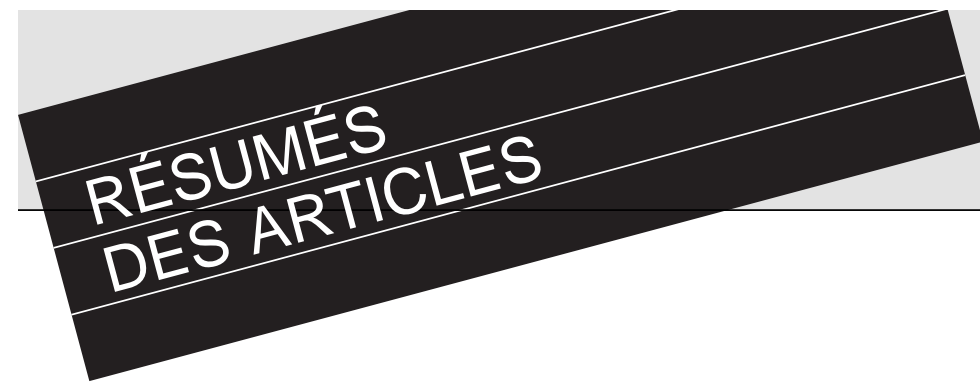

FRANÇAIS

Tribologie du laminage à froid de tôles 125

\section{P. Montmitonnet}

Le laminage dépend de manière critique du frottement et de la lubrification, tant pour le contrôle du procédé que pour la qualité du produit fini. Pechiney et Usinor ont donc entrepris en 1995, en partenariat avec le CNRS, un ambitieux projet regroupant sept laboratoires publics autour de l'Irsid et du Centre de Recherches de Voreppe, sur les deux grands domaines de la lubrification : mécanique de la formation du film lubrifiant entre surfaces rugueuses déformables, et formation des films limites (tribochimie), en vue de construire un modèle de laminage incluant un modèle de frottement prédictif et local. Ce sont les efforts et les résultats de ce CPR (Contrat de Programme de Recherches) " Mise en Forme des Matériaux : contact métal-outil-lubrifiant " qui sont décrits dans ce numéro et un numéro ultérieur de Science et Génie des Matériaux.

Formation et évolution des couches superficielles de deux alliages métalliques (AI-Mg, acier IF-Ti) au cours du laminage à

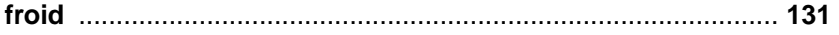
G. Plassart, A.-M. Huntz, R. Penelle, M. Aucouturier

Afin d'améliorer un modèle de lubrification en laminage à froid, les effets de ce procédé sur la formation et l'évolution des couches superficielles des deux alliages sont étudiés par analyses de surface et microscopies couplées. Sur l'alliage Al-Mg, le frottement sur les aspérités du métal et leur écrasement provoquent par écrouissage et échauffement localisés l'enfouissement de débris dans le substrat, la recristallisation du métal sur $250 \mathrm{~nm}$ et sa restauration sur $20 \mu \mathrm{m}$. Sur l'acier, la couche d'oxyde devient principalement amorphe et plastique, en raison d'une incorporation importante de lubrifiant, et hétérogène à l'échelle nanoscopique.

Rhéologie du lubrifiant en conditions réelles : mesures et confrontation à un contact bille/disque

J. Molimard, M. Querry, P. Vergne

Lors du laminage à froid des tôles minces en alliages métalliques, la maîtrise de la lubrification constitue un des problémes industriels majeurs. L'étude rapportée dans cet article a pour objet la caractérisation rhéologique de deux lubrifiants industriels, dans des conditions proches de celles rencontrées en laminage. L'application de modèles EHD permet alors un calcul de l'épaisseur de film lubrifiant, qui est comparée aux valeurs issues de mesures par interférométrie dans un contact bille/disque.

Un tribomètre analytique sous ultra-vide et son application à la tribochimie du laminage 149 M. Boehm, C. Grossiord, T. Le Mogne, J.-M. Martin

Dans les procédés de laminage à froid, l'augmentation de la productivité et l'amélioration de l'aspect des surfaces nécessitent la compréhension des mécanismes de lubrification. En particulier, le frottement d'origine limite est contrôlé par la physico-chimie des additifs. Ces phénomènes sont complexes et nécessitent une approche simplifiée. Une méthode originale a été développée : un tribomètre UHV et des techniques d'analyse de surfaces simulent la réactivité chimique des molécules.
Summaries of articles

Resumenes de los articulos

Inhalt der Artikel
Tribochimie du laminage à froid : étude par ToF-SIMS de la chimisorption sur la tôle des additifs du lubrifiant ................. 159 G. Dauchot, R. Combarieu, P. Montmitonnet, M. Repoux, G. Dessalces, F. Delamare

La chimisorption des additifs de lubrifiant de laminage à froid sur un acier et un alliage d'aluminium est étudiée par spectrométrie de masse ToF-SIMS. L'étude préparatoire de l'adsorption des divers additifs permet de mettre en évidence leur rôle individuel, les compétitions d'adsorption, les seuils thermiques de désorption ou de décomposition. Ces résultats sont validés par des essais sur laminoir pilote.

Mise en évidence directe d'écoulements avec glissement à la paroi à diverses interfaces hexadécane-solide .................... 169 R. Pit, H. Hervet, L. Léger

La condition aux limites pour la vitesse d'écoulement à la paroi pour un fluide Newtonien à diverses interfaces solide/liquide a été étudiée expérimentalement au moyen d'une technique originale à haute résolution. Un glissement interfacial notable a été mis en évidence pour de l'hexadécane en écoulement sur une surface peu rugueuse et recouverte de groupements méthyles (surface non mouillante pour l'hexadécane). L'étude systématique de différentes surfaces modifiées a permis d'identifier deux paramètres clés fixant l'amplitude du glissement à la paroi et agissant de façon antagoniste : la rugosité de la surface (géométrique et chimique) et la force des interactions fluide/surface.

Autres articles

Etude des effets de structuration au sein de films minces de

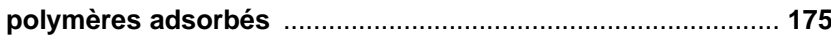
M. Brogly

La détermination de l'état d'organisation de l'interface polymère/métal est indispensable à la compréhension des aspects moléculaires de l'adhésion. Des films minces de polymères adsorbés ont été étudiés par spectroscopie infrarouge de réflexion-absorption. II est montré que des forces motrices de type acide-base sont susceptibles de structurer les chaînes à l'interface. En particulier, l'influence de la microstructure des chaînes sur l'orientation moléculaire, la densité de connecteurs interfaciaux et l'adhésion, est étudiée à l'échelle du nanomètre.

Méthodes pour l'étude de l'effet de la mise en forme des systèmes sandwich acier/polymère/acier sur le niveau d'adhérence acier/polymère ............................................................ 185 J. Guillemenet, S. Bistac, P. Deprez, P. Junges, J. Schultz

L'objectif de l'étude est de déterminer l'influence quantitative de la mise en forme (emboutissage, pliage...) sur les propriétés d'adhérence de systèmes acier/polymère/acier grâce à deux tests d'adhérence complémentaires (rupture en mode I et II) : le test de clivage en coin et la torsion par cisaillement. Les résultats, confrontés aux caractéristiques mécaniques de la résine, permettent de définir de premiers critères simples d'emboutissabilité.

Comportement à l'oxydation sous air entre 1200 et $1400^{\circ} \mathrm{C}$ du $\beta$-NiAl élaboré par métallurgie des poudres .......................... 193 B. Heusler-Sourkounis, M. Göbel, G. Borchardt,

R. Baccino, B. Lesage

L'oxydation sous air d'échantillons de $\beta$-NiAl élaborés par pression isostatique à chaud de poudres a été étudiée entre 1200 et $1400^{\circ} \mathrm{C}$. À 1200 et $1400^{\circ} \mathrm{C}$, la couche d'alumine se développe selon une loi 
parabolique. L'oxydation catastrophique observée à $1300^{\circ} \mathrm{C}$ a pu être évitée par un traitement préalable à $1200^{\circ} \mathrm{C}$ sous une faible pression partielle d'oxygène. L'oxydation en deux étapes $\left({ }^{16} \mathrm{O}_{2}\right.$ puis $\left.{ }^{18} \mathrm{O}_{2}\right)$ a permis d'affirmer que l'oxydation a lieu par transport intergranulaire d'oxygène vers l'interface substrat-oxyde.

\section{Applications de l'effet Barkhausen et du pouvoir thermo- électrique au suivi des évolutions microstructurales des alliages métalliques \\ X. Kléber, R. Borrelly, A. Vincent}

Dans cet article, nous rappelons brièvement les mécanismes physiques à l'origine de l'effet Barkhausen dans les métaux ferromagnétiques et du pouvoir thermoélectrique dans les métaux conducteurs. Nous présentons ensuite, pour chacun de ces deux phénomènes, les principes de mesure et leur sensibilité à l'état microstructural, notamment dans le cas des phénomènes de précipitation et dans ceux liés à la déformation plastique. Enfin, dans le cas de la formation de précipités dans un alliage à base de fer, nous montrons la complémentarité des deux techniques.

Applications de l'imagerie acoustique de très haute fréquence à la caractérisation locale des matériaux 215 B. Cros

L'imagerie acoustique de très haute fréquence $(1 \mathrm{GHz})$ présente une résolution micronique. Par son caractère d'imagerie de sous-surface, elle est bien adaptée à la caractérisation de la porosité. Support de mesures quantitatives par acquisition de la signature acoustique, elle fournit des informations suffisamment localisées pour caractériser les propriétés élastiques propres à chacun des constituants d'un minicomposite $\mathrm{SiC} / \mathrm{SiC}$, la fibre et la matrice.

\section{ENGLISH}

Tribology of strip cold rolling

P. Montmitonnet

Strip rolling processes depend critically on friction and lubrication for process control as well as for strip quality. Pechiney and Usinor companies have therefore joined with CNRS (National Scientific Research Centre of France) to build an ambitious project gathering seven French public laboratories and their own research centres, Irsid and Centre de Recherches de Voreppe. The two major fields of lubrication were addressed : the formation of fluid lubricant films between rough deformable surfaces, and the formation of boundary films (tribochemistry). The final purpose was to derive a model of rolling processes including a predictive, local friction model. This issue and a future issue of Science et Génie des Matériaux present the efforts and the results of this Research Programme Contract «Materials forming : metal - tools - lubricant contact».

Formation and evolution during cold rolling of the surface layers of two metal alloys (Al-Mg, IF-Ti steel) 131 G. Plassart, A-M. Huntz, R. Penelle, M. Aucouturier

In order to improve a cold rolling lubrication model, the effects of this process on the formation and evolution of superficial layers in two alloys were studied by coupled surface and microscopy analysis. On the Al-Mg alloy, the friction on the metal asperities and their crushing provoke, by localized hardening and heating, the burying of debris in the substrate, the recrystallization of the metal within a layer of $250 \mathrm{~nm}$ and its recovery down to $20 \mu \mathrm{m}$. On the steel, the oxide layer mainly becomes amorphous and plastic, because of a high incorporation of the lubricant, and heterogeneous at the nanoscopic scale.
Lubricant rheology in real conditions : measurements and confrontation with a ball/disk contact ................................ 141 J. Molimard, M. Querry, P. Vergne

During the cold rolling of metal alloy sheets, the control of lubrication constitutes one of the major industrial problems. The aim of the study reported in this article concerns the rheological characterization of two industrial lubricants, under conditions close to those met in rolling. The application of EHD models then allows to calculate the lubricant film thickness, which is compared to the values measured by interferometry in a ball/disk contact.

An analytical ultra-high vacuum tribometer : application to tribochemistry in metal rolling 149

M. Boehm, C. Grossiord, T. Le Mogne, J.-M. Martin

The demand for improvements in surface quality and increased productivity in industrial cold metal rolling requires a good understanding of lubrication mechanisms. The limitations are due to boundary friction, controlled by the physico-chemistry of lubricant additives. The phenomena are complex and require a simplified approach. Consequently, a new method was developed by using an UHV tribometer associated with surface analytical tools to simulate the molecule chemical reactivity toward surfaces.

Tribochemical reactions in cold rolling : a ToF-SIMS study of the chemisorption of the lubricant additives on the sheet .......... 159 G. Dauchot, R. Combarieu, P. Montmitonnet, M. Repoux, G. Dessalces, F. Delamare

The chemisorption of cold rolling oil additives on steel and aluminium surfaces is studied with a mass spectrometry technique, ToF-SIMS. Preliminary experiments underline adsorption competition, and thermal threshold for desorption or decomposition. This results fit well with experimental cold rolling results.

Direct experimental evidences for flow with slip at hexadecane solid interfaces ............................................................... 169 R. Pit, H. Hervet, L. Léger

The limit condition for the flow rate at the wall for a Newtonian fluid with various solid/liquid interfaces was studied experimentally using an original high resolution technique. A notable interfacial slipping was shown for the hexadecane flowing on a surface with low roughness and covered with methyl groups (non wetting surface for the hexadecane). The systematic study of various modified surfaces made it possible to identify two key parameters fixing the amplitude of slipping at the wall and acting in an antagonistic way on the roughness of the surface (geometric and chemical) and the fluid/ surface interactions.

\section{Adsorption induced ordering effects in thin polymer films}

175 M. Brogly

The understanding of the molecular aspects of adhesion needs the determination of the molecular order of macromolecular chains at the polymer/metal interface. Thin supported polymer films are studied by FTIR reflectance analysis (IRRAS). It is shown that the development of specific acid-base interactions at the interface is able to strongly organize and order macromolecular chains at the vicinity of the interface. Microstructural parameters of the polymer are shown to influence both interfacial organization and adhesion.

Method for studying the influence of forming sheet steel laminates on the adhesion polymer/steel 185 J. Guillemenet, S. Bistac, P. Deprez, P. Junges, J. Schultz

The objective of the study is to determine the influence of forming on the adherence properties of sheet steel laminates. Drawing is then 
decomposed in different deformation modes : stretching (or biaxial tension), plane strain tension, uniaxial tension and shear deformation. Two adherence tests are used - the torsion shear test (napkin-ring) and the wedge test - in order to evaluate the metal/polymer adhesion before and after deformation.

Oxidation behaviour of a PM $\beta$-NiAl material in air at $1200^{\circ} \mathrm{C}<\mathrm{T}$ $<1400^{\circ} \mathrm{C}$ 193

B. Heusler-Sourkounis, M. Göbel, G. Borchardt,

R. Baccino, B. Lesage

The oxidation behaviour of a $\beta$-NiAl material (produced by powder metallurgy) was investigated in the temperature range $1200^{\circ} \mathrm{C}<\mathrm{T}<$ $1400^{\circ} \mathrm{C}$. In isothermal runs at 1200 and $1400^{\circ} \mathrm{C}$, an alumina scale grew according to a parabolic growth law. At $1300^{\circ} \mathrm{C}$, catastrophic oxidation was observed, but a short anneal at low oxygen partial pressure at $1200^{\circ} \mathrm{C}$, prior to the oxidation at $1300^{\circ} \mathrm{C}$, initiated a parabolic scale growth. Further, cyclic oxidation tests were carried out and the growth mechanism of the scale was identified by two-stage oxidation $\left({ }^{16} \mathrm{O}_{2} /{ }^{18} \mathrm{O}_{2}\right)$ in combination with SNMS isotope profile analysis.

Barkhausen noise and thermoelectric power applied to study microstructural evolutions in metallic alloys 201

X. Kléber, R. Borrelly, A. Vincent

In this article, we briefly recall the physical mechanisms at the origin of the Barkhausen effect in ferromagnetic mediums and the thermoelectric power in conductor metals. We then present, for each of these phenomena, the measurement principles and their sensitivity to the microstructural state, notably in the case of precipitation phenomena and in the ones linked to plastic deformation. Finally, in the case of the formation of precipitates in an iron-based alloy, we show the complementarity of both techniques.

Applications of very high frequency acoustical imaging to the local characterization of materials 215

B. Cros

$1 \mathrm{GHz}$ very high frequency acoustical imaging displays a micronic resolution. Owing to its nature of sub-surface imaging, it is well adapted to the characterization of porosity. Used as a means for quantitative measurements through acoustic signature processing, it provides sufficiently localized information to characterize the elastic properties proper to each component of a $\mathrm{SiC} / \mathrm{SiC}$ minicomposite, the fiber and the matrix.

\section{ESPAÑOL}

Tribología del laminado en frio de las chapas

P. Montmitonnet

El laminado depende de manera crítica del frotamiento y de la lubricación, tanto para el control del procedimiento como para la calidad del producto acabado. Pechiney y Usinor han emprendido en 1995, conjuntamente con el CNRS, un ambicioso proyecto reagrupando siete laboratorios públicos alrededor del Irsid y del Centro de Investigaciones de Voreppe, sobre los dos grandes campos de la lubricación : mecánico de la formación de la película lubricante entre superficies rugosas deformables, y formación de películas límites (triboquímica), con vistas a construir un modelo de laminado incluyendo un modelo de frotamiento predictivo y local. Estos son los esfuerzos y los resultados de este CPR (Contrato de Programa de Investigaciones) «Conformación de los materiales : contacto metal - herramienta - lubricante» que son descritos en este número y en un numero ulterior de "Science et Génie des Matériaux ».
Formación y evolución de las capas superficiales de dos aleaciones metálicas ( $\mathrm{Al}-\mathrm{Mg}$, acero IF-Ti) durante el laminado en frio .. 131 G. Plassart, A.-M. Huntz, R. Penelle, M. Aucouturier

Con el fín de mejorar un modelo de lufrificación en el laminado en frio, los efectos de este procedimiento sobre la formación y la evolución de las capas superficiales de las dos aleaciones son estudiadas por análisis de superficie y microscopías acopladas. Sobre la aleación $\mathrm{Al}-\mathrm{Mg}$, el frotamiento sobre las asperezas del metal y su aplastamiento provocado por el tratamiento en frio y calentamientos localizados el enterramiento de residuos en el sustrato, la recristalización del metal en $250 \mathrm{~nm}$ y su restauración sobre $20 \mu \mathrm{m}$. Sobre el acero, la capa de óxido se hace principalmente amorfa y plástica, en razón de una incorporación importante de lubricante, y heterogénea a escala nanoscópica.

Reología del lubricante en condiciones reales : medidas y confrontación de un contacto bola-disco ......................... 141 J. Molimard, M. Querry, P. Vergne

A partir del laminado en frio de las chapas delgadas en aleaciones metálicas, la matriz de la lubrificación constituye uno de los mayores problemas industriales. El estudio reproducido en este artículo tiene por objeto la caracterización reológica de dos lubricantes industriales en condiciones próximas a las encontradas en el laminado. La aplicación de modelos EHD permite entonces un cálculo del espesor de la película lubricante, que se compara con los valores sacados de medidas por interferometría en un contacto bola/disco.

Un tribómetro analítico bajo ultra-vacío y su aplicación a la triboquímica del laminado

M. Boehm, C. Grossiord, T. Le Mogne, J.-M. Martin

En los procedimientos de laminado en frío, el aumento de la productividad y la mejora del aspecto de las superficies necesitan la comprensión de los mecanismos de lubricación. En particular, el frotamiento de origen límite se controla por la fisicoquímica de los aditivos. Estos fenómenos son complejos y necesitan una aproximación simplificada. Se ha desarrollado un método original : un tribómetro UHV y las técnicas de anílisis de superficie simulan la reactividad química de las moléculas.

Triboquímica del laminado en frio : estudio por ToF-SIMS de la quimisorpción de los aditivos de lubricantes en la chapa .... 159 G. Dauchot, R. Combarieu, P. Montmitonnet,

M. Repoux, G. Dessalces, F. Delamare

La quimisorpción de los aditivos de lubricantes de laminado en frio en un acero y en una aleación de aluminio se estudia por espectrometría de masa ToF-SIMS. El estudio preparatorio de la adsorción de los diversos aditivos permite poner en evidencia su papel individual, las competiciones de adsorción, los umbrales térmicos de desorción o de descomposición. Estos resultados son validados por los ensayos en el laminador piloto.

Puesta en evidencia directa de flujo con deslizamiento de la pared con diversas intercaras hexadecano-sólida 169 R. Pit, H. Hervet, L. Léger

La condición en los límites para la velocidad de circulación de la pared para un fluido Newtoniano con diversas intercaras sólido/líquido se ha estudiado experimentalmente por medio de una técnica original de alta resolución. Un deslizamiento interfacial notable se ha puesto en evidencia por el hexadecano en circulación sobre una superficie poco rugosa y recubierta por grupos metílos (superficie no mojante por el hexadecano). El estudio sistemático de diferentes superficies modificadas ha permitido identificar dos 
parámetros llave fijando la amplitud del deslizamiento de la pared y actuando de forma antagonista : la rugosidad de la superficie (geometría y química) y la fuerza de las interacciones fluido/ superficie.

Estudio de los efectos de estructuración en el seño de películas delgadas de polimeros adsorbidos M. Brogly

La determinación del estado de organización de la intercara polímero/metal es indispensable para la comprensión de los aspectos moleculares de adhesión. Las películas delgadas de polímeros adsorbidos han sido estudiadas por espectroscopía infraroja de reflexión-adsorción. Se muestra que las fuerzas motrices del tipo ácido-base son suceptibles de estructurar las cadenas de la interfase. En particular, la influencia de la microestructura de las cadenas sobre la orientación molecular, la densidad de conectores interfaciales y la adhesión se estudia a escala del nanómetro.

Metodos para el estudio del efecto de la puesta en forma de los sistemas sandwich acero/polímero/acero sobre el nivel de la adherencia acero/polímero...................................................... 185

J. Guillenemet, S. Bistac, P. Deprez, P.Junges, J. Schultz

El objetivo del estudio es determinar la influencia cuantitativa de la puesta en forma (embutición, plegado...) sobre las propiedades de adherencia de sistemas acero/polímero/acero gracias a dos ensayos de adherencia complementarios (ruptura en modo I y II) : el ensayo de hendidura en cuña y la torsión por cizallamiento. Los resultados, confrontados a las características mecánicas de la resina, permiten definir los primeros criterios simples de la embutición.

Comportamiento a la oxidación bajo aire entre 1200 y $1400^{\circ} \mathrm{C}$ de $\beta$-NiAl elaborado por metalúrgia de polvos .......................... 193

B. Heusler-Sourkounis, M. Göbel, G. Borchardt,

R. Baccino, B. Lesage

La oxidación bajo aire de muestras de $\beta-\mathrm{NiAl}$ elaboradas por presi6n isostatica en caliente de polvos se ha estudiado entre 1200 y $1400^{\circ} \mathrm{C}$. A 1200 y $1400^{\circ} \mathrm{C}$, la capa de alumina developase según una ley parabólíca. La oxidación catastrófica observada a $1300^{\circ} \mathrm{C}$ ha podido evitarse por un tratamiento previo a $1200^{\circ} \mathrm{C}$ bajo una débil presión parcial de oxígeno. La oxidación en dos etapas $\left({ }^{16} \mathrm{O}_{2}\right.$ después $\left.{ }^{18} \mathrm{O}_{2}\right)$ ha permitido afirmar que la oxidación ha tenido lugar por transporte intergranular de oxígeno hacia la interfase sustrato-óxido.

Aplicaciones del efecto Barkhausen y del poder termoeléctrico al seguido de evoluciones microestructurales de las aleaciones metálicas 201

X. Kléber, R. Borrelly, A. Vincent

En este artículo, se pasa brevemente revista a los mecanismos físicos del origen del efecto Barkhausen en los metales ferromagnéticos y del poder termoeléctrico en los metales conductores. Presentamos seguidamente, para cada uno de estos dos fenómenos, los principios de medida y su sensibilidad en el estado microestructural, especialmente en el caso de los fenómenos de precipitación y en los ligados a la deformación plástica. Finalmente, en el caso de la formación de precipitados en una aleación a base de hierro, se muestra la complementaridad de las dos técnicas.

Aplicaciones de la estamperia acústica de muy alta frecuencia a la caracterización local de los materiales 215 B. Cros

La estamperia acústica de muy alta frecuencia (1 GHz) presenta una resolución micrónica. Por su caracter de imagen sub-superficial, está bien adaptada a la caracterización de la porosidad. Soporte de medidas cuantitativas por adquisición de la señal acústica, suministra informaciones suficientemente localizadas para caracterizar las propiedades elásticas limpias de cada uno de los constituyentes de un minicompuesto $\mathrm{SiC} / \mathrm{SiC}$, la fibra y la matríz.

\section{DEUTSCH}

Tribologie beim Kaltwalzen von Blechen 125

P. Montmitonnet

Das Walzen hängt in kritischer Weise von der Reibung und der Schmierung ab, sowohl bei der Überwachung des Verfahrens als auch bei der Qualität des Endproduktes. Péchiney und Usinor nahmen deshalb 1995 ein anspruchsvolles Projekt in Angriff, in Partnerschaft mit dem CNRS und unter Beteiligung von sieben öffentlichen Laboratorien zusammen mit Irsid und dem Forschungszentrum von Voreppe, über die zwei grossen Bereiche der Schmierung : die Mechanik der Bildung des Schmierfilms zwischen rauhen verformbaren Flächen, und die Bildung von Grenzfilmen (Tribochemie), beides im Hinblick auf die Entwicklung eines Walzmodells in dem ein Modell zur Vorhersage und lokalen Beschreibung der Reibung einbegriffen wäre. Die Anstrengungen und Ergebnisse dieses CPR (Contrat de Programme de Recherches) über die « Formgebung von Werkstoffen : Kontakt MetallWerkzeugSchmiermittel », sind in dieser und einer weiteren Ausgabe von «Science et Génie des Matériaux » beschriesben.

Bildung und Verlauf der Oberflächenschichten von zwei metallischen Legierungen (AIMg, IF-Titan Stahl) während des Kaltwalzens

G. Plassart, A.-M. Huntz, R. Penelle, M. Aucouturier

Um ein Modell für die Schmierung beim Kaltwalzen zu verbessern, wurden die Auswirkungen dieses Verfahrens auf die Bildung und den Verlauf von Oberflächenschichten bei zwei Legierungen durch Oberflächenanalysen und Mikroskopie, untersucht. Bei der Al-MgLegierung ruft die Reibung auf den Rauheitsspitzen des Metalls und ihr Zusammenstauchen, durch Kaltverfestigung und örtliche Erwärmung ein Eindringen der Trümmer in die Unterlage hervor, wobei die Rekristallisation des Metalls über $250 \mathrm{~nm}$ und ihre Erholung über $20 \mu \mathrm{m}$ erfolgt. Auf Stahl wird die Oxidschicht hauptsächlich amorph und plastisch, aufgrund einer bedeutenden Einlagerung von Schmiermittel, und heterogen im Nanometerbereich

Rheologie des Schmiermittels unter betriebsnahen Bedingungen : Messung und Vergleich mit dem Kontaktverhalten zwischen einer Kugel und einer Scheibe ............................ 141 J. Molimard, M. Querry, P. Vergne

Während des Kaltwalzens von Feinblechen aus metallischen Legierungen stellt die Beherrschung des Schmierens eines der Hauptprobleme im Betrieb dar. Die Untersuchung, über die in diesem Beitrag berichtet wird, hat die rheologische Beschreibung von zwei industriellen Schmiermitteln unter walznahen Bedingungen zum Ziel. Die Anwendung von EHD Modellen ermöglicht dann eine Berechnung der Dicke des Schmierfilms, die mit Werten aus interferometrischen Messungen bei einem Kontakt Kugel- Scheibe verglichen wird.

Ein analytisches Hochvakuum Tribometer und seine Anwendung bei der Tribochemie des Walzens 149

M. Boehm, C. Grossiord, T. Le Mogne, J.-M. Martin

Bei den Kaltwalzverfahren erfordert die Erhöhung der Produktivität und die Verbesserung des Oberflächenaussehens das Verstehen der Schmierungsmechanismen. Insbesondere die Grenzreibung wird 
durch die physikalische Chemie der Additive kontrolliert. Diese Erscheinungen sind komplex und verlangen eine vereinfachte Näherung. Eine neuartige Methode wurde entwickelt : ein UHV-Tribometer und Analysetechniken für die Oberfläche simulieren die chemische Reaktionsfähigkeit der Moleküle.

\section{Tribochemie des Kaltwalzens : Untersuchung der Chemisorption} von Additiven mittels der ToF-SIMS 159

G. Dauchot, R. Combarieu, P. Montmitonnet, M. Repoux,

G. Dessalces, F. Dalamare.

Die Chemisorption von Schmiermitteladditiven beim Kaltwalzen wurde auf einem Stahl und einer Aluminium-Legierung mit der ToF-SIMS-Massenspektrometrie untersucht. Die einleitende Untersuchung der Adsorption verschiedener Additive erlaubte den Nachweis ihrer individuellen Rolle, die Konkurrenzwirkung der Additive, die thermischen Schwellen der Desorption oder der Zersetzung. Diese Ergebnisse wurden durch Versuche auf einem Pilotwalzwerk bestätigt.

Direkter Nachweis von Fliessvorgängen mit Gleitung auf der Trennwand bei verschiedenen Zwichenflächen HexadekanFestkörper .169

R. Pit, H. Hervet, L. Léger

Die Grenzbedingungen für die Fliessgeschwindigkeit auf der Trennwand für eine Newton'sche Flüssigkeit auf verschiedenen Oberflächen fest/flüssig wurden experimentell mittels einer neuartigen Technik mit hoher Auflösung untersucht. Eine deutliche Zwischenflächengleitung wurde auf einer wenig rauhen Oberfläche, die von Methylgruppen bedeckt war, bei fliessendem Hexadekan nachgewiesen (Oberfläche von Hexadekan nicht benetzt). Die systematische Untersuchung verschiedener modifizierter Oberflächen ermöglichte zwei Schlüsselparameter zu identifizieren, die die Gleitamplitude auf der Wand bestimmen und in gegensätzlicher Weise reagieren : die Rauheit der Oberfläche (geometrisch und chemisch) und die Stärke der Wechselwirkungen Flüssigkeit/ Oberfläche.

Untersuchung der Wirkungen der Strukturierung inmitten von Dunnfilmen adsorbierter Polymere 175 M. Brogly

Die Bestimmung des Organisationszustandes der Zwischenfläche Polymer/ Metall ist unentbehrlich für das Verständnis molekularer Aspekte der Adhäsion. Es wurden Dünnfilme adsorbierter Polymere mittels der Infrarot-Reflexions-Absorptions-Spektrographie untersucht. Es wird gezeigt, dass die treibenden Kräfte vom Typ Säure- Base dazu neigen, die Ketten auf der Zwischenfläche zu strukturieren. Insbesondere wurde der Einfluss der Mikrostruktur der Ketten auf die molekulare Orientierung, die Dichte der Zwischenflächenverbinder und die Adhäsion im Nanometerbereich untersucht.

Methodik für die Untersuchung des Einflusses der Formgebung auf die Haftfestigkeit bei Systemen Stahl/ Polymer/ Stahl .... 185 J. Guillemenet, S. Bistac, P. Deprez, P. Junges, J. Schultz

Ziel der Untersuchung ist, den quantitativen Einfluss der Formgebung (Ziehen, Biegen ) auf die Adhäsionseigenschaften der Systeme Stahl/ Polymer/ Stahl mit zwei komplementären Adhäsionsversuchen (Bruch im Modus I und II) zu bestimmen : dem Spaltversuch mit Keil und dem Torsionsscherversuch. Die Ergebnisse, im Vergleich mit den mechanischen Werten des Kunststoffs, erlauben die ersten einfachen Kriterien fur die Tiefziehbarkeit zu definieren.
Verhalten von pulvermetallurgisch hergestelltem $\beta$-NiAl bei der Oxidation zwischen $1200^{\circ}$ und $1400^{\circ} \mathrm{C}$ in Luft

B. Heusler-Sourkounis, M. Göbel, G. Borchardt,

R. Baccino, B. Lesage

Es wurde die Oxidation zwischen $1200^{\circ}$ und $1400^{\circ} \mathrm{C}$ in Luft von $\beta$-NiAl Proben, die pulvermetallurgisch durch isostatisches Pressen in der Wärme hergestellt wurden, untersucht. Bei 1200 und $1400^{\circ} \mathrm{C}$ wächst die Oxidschicht parabolisch. Die oberhalb $1300^{\circ} \mathrm{C}$ beobachtete katastrophale Oxidation konnte durch eine vorhergehende Behandlung bei $1200^{\circ} \mathrm{C}$ unter einem niedrigen Partialdruck von Sauerstoff vermieden werden. Die Oxidation in zwei Stufen $\left({ }^{16} \mathrm{O}_{2}\right.$ dann ${ }^{18} \mathrm{O}_{2}$ ) bestätigte, dass die Oxidation über den interkristallinen Transport des Sauerstoffs zu der Zwischenfläche TrägerwerkstoffOxid statffindet.

Anwendungen des Barkhausen- und des thermoelektrischen Effektes auf die Charakterisierung der Mikrostruktur in metallischen Legierungen ................................................ 201 X. Kléber, R. Borrelly, A. Vincent

In diesem Bericht wird kurz an die physikalischen Mechanismen erinnert, die am Ursprung des Barkhausen- Effektes in ferromagnetischen Werkstoffen und der thermoelektrischen Kraft in leitenden Metallen sind. Danach werden für jede dieser zwei Erscheinungen die Messprinzipien und ihre Empfindlichkeit gegenüber des Mikrogefüges vorgestellt, besonders für den Fall der Ausscheidungserscheinungen und in denjenigen, die mit der plastischen Verformung zusammenhängen. Abschliessend wird am Beispiel der Bildung der Ausscheidungen in einer EisenbasisLegierung gezeigt, wie sich die zwei Verfahren ergänzen.

Anwendungen der akustischen Abbildung sehr hoher Frequenz für die lokale Beschreibung von Werkstoffen 215 B. Cros

Die akustische Abbildung sehr hoher Frequenz (1 GHz) liefert eine Auflösung im Mikronbereich. Durch ihre Besonderheit die Werkstoffbeschaffenheit unterhalb der Öberfläche darstellen zu können, ist sie zur Beschreibung der Porosität gut geeignet. Sie führt zu quantitativen Bestimmungen durch die Beschaffung der akustischen Abzeichnung, und sie liefert ausreichend örtliche und genaue Informationen für die Beschreibung der elastischen Eigenschaften für jeden einzelnen Bestandteil eines Miniverbundwerkstoffs SiC/SiC, der Faser und der Grundmasse. 